$\xi=-$ 圆

\title{
Design of Student Worksheets based on Learning Cycle to Improve Ability of Mathematics Representation Students of Class VIII Junior High School in Indonesia
}

\author{
Hasanatul Fu'adah Amran'*, Suparman ${ }^{2}$ \\ ${ }^{1,2}$ Master of Mathematics Education, Ahmad Dahlan University, Indonesia \\ *Corresponding author E-mail: fuadah.amran19@gmail.com
}

\begin{abstract}
Mathematical representation is very important for students because it can affect students regarding material and problem-solving. Application of the 5E learning cycle learning model can help overcome student difficulties in mathematical modeling and geometry understanding. Student worksheets simplify the execution of the learning cycle and can train the ability of mathematical representation. This article aims to develop learning products in the form of a Learning Cycle-based student worksheet that is oriented towards students mathematical representation abilities. This research is development research with 4D: define, design, development, and dissemination. This research was conducted in class VIII MTs Mu'allimmat Yogyakarta, Indonesia. Subjects in this research were teachers, students, material experts and media experts. Data collection methods used in this research are interviews, questionnaires, and tests. Instruments used in the form of validation sheet, teacher response questionnaire, student response questionnaire, mathematical representation and interview guidance test. The first stage in this research is the analysis of student needs on the student worksheet. The results of the analysis aim to simplify the process of designing student worksheets. The learning cycle stages of Engage make student worksheet design, Explore, Explain, Elaborate, and Evaluate. Pretest and posttest will measure the improvement of students' mathematical representation before and after the use of student worksheets. This research is limited to the design phase. For further research will proceed at the stage of development and dissemination.
\end{abstract}

Keywords: 4D; learning cycle; mathematical representation; worksheets

\section{Introduction}

National Council of Teachers of Mathematics (NCTM) [1] which states that in the implementation of learning mathematics in schools, there are five standards that must be achieved in learning, which include: (1) mathematical communication; (2) mathematical reasoning; (3) mathematical problem solving; (4) mathematical connection; and (5) mathematical representation. This is in line with the real learning in Indonesia where the curriculum was implemented in 2013. The contents of Curriculum 2013 aims to have students problem-solving skills, using reasoning and communicating ideas. Also, in the learning done in the school also requires students to be able to represent everyday problems in the mathematical model.

According to NCTM [1], representation is the basis of how one can understand and use their ideas. Mathematical representation is a process of modeling something from the real world into a more abstract form of the symbol [2]. Representations have a significant effect on helping students solve problems they find [3]. The ability of mathematical representation is one of the general goals of learning mathematics in schools. This ability is essential for learners and closely related to communication skills and problem-solving. The knowledge of students' intelligent representation and understanding is crucial in finding the right problem-solving solution [4-5]. Thus, it can be concluded that the ability of representation is the ability of students in modeling the real things that exist in the environment into something more concrete or abstract.
Some authors suggest that mathematical representation skills are important in learning mathematics in school [2,4,6-9]. Some of the representational functions in classroom learning are: (1) providing an idea of how students think about an idea or a mathematical context; (2) provide information on the tendency of thinking among students; and (3) as a tool in the learning process in the classroom [6]. Mathematical representation and self-efficacy lead to a degree of influence on students' material content and motivation [6]. Students with high self-efficacy can easily solve problems, present data or information into symbol form. In explaining the problem involves the ability of visual representation in the form of sketches, symbols, formulas and mathematical models [11]. Students who use visual representation more easily in problem-solving, also, the use of visual representation is helpful in solving verbal math problems [12].

In fact, the ability of students in representing mathematical problems is still relatively low. This is shown based on the results of PISA 2015 where Indonesia's average score for Science 403, Mathematics 387 and Reading 397 [13]. This result is an increase compared to the year 2012 where Indonesia is in position 63 of 64 countries with an average score of 375 . However, when compared with other countries, the results achieved by Indonesia is still said in the low category. Indonesia is only able to rank the bottom 10 of 76 states. About that result of observation and field interview, the ability of representation of Grade VIII students of MTs Mu'allimat Yogyakarta is still classified in the low category. Students still have difficulty in making equations or mathematical models of the given problem and in solving problems by involving math- 
ematical expressions. Also, students have not been able to write a clear and orderly completion stage. Based on this, efforts are needed to improve students' mathematical representation.

In classroom learning the teacher can provide learning with abstract concepts to train students' mathematical representation skills [14]. One effort to improve the ability of representation is by determining a model of learning that prioritizes the activity in students to be able to explore students' thinking ability. Learning model that can be used is the learning cycle 5E. Learning cycle is a learning model in the science of education that is consistent with contemporary theories about how individuals learn [15]. Learning cycle was first introduced by Robert Karplus in Science Curriculum Improvement Study or SCIS [16]. Learning cycle 5E helps students to be active in learning done in the classroom as well as deepen understanding of student concepts [17]. Learning cycle 5E is effective learning to develop 21st-century skills especially mathematical representation [18]. Learning Cycle 5E not only gives an impact on improving student achievement but also makes learning more meaningful for students [19]. In the learning cycle model, there are five stages of engagement, exploration, explanation, elaboration/extension, and evaluation [15]. These five stages are then known as $5 \mathrm{E}$.

Application of 5E learning cycle learning model is beneficial in overcoming students' difficulties in mathematical modeling and understanding of geometry [20]. Student learning outcomes that follow the 5E learning cycle learning model is better than students who follow conventional learning. Also, students are also actively involved in developing the lessons learned [21]. Learning cycle can be used as an alternative learning model to improve mathematical thinking skills in solving algebraic problems, beliefs, and attitudes towards mathematics [22].

In the implementation of the $5 \mathrm{E}$ learning cycle in school, it takes teaching materials, media or instrument that can help in learning activities in the classroom. One of the alternatives that can be done by teachers is to develop teaching tools Student Worksheet. Student worksheets facilitate student-centered learning and assist students in building their knowledge and improving students problem-solving skills [23]. Also, student worksheets were created to help students relate the problem to the subject matter with daily life [24]. However, in reality in school, there is still no worksheet of students oriented to learning cycle $5 \mathrm{E}$ and can help students in improving the ability of the representation it has. Based on this, this article proposes the design of the development of student workbooks based on the learning cycle $5 \mathrm{E}$ and oriented to the ability of representation.

\section{Method}

The research method used in the development of this student worksheet is a development method known as Research and Development ( $R \& D)$. Where this method is used to develop a product. This research extends Student Worksheet based on the learning cycle and oriented to students' mathematical representation ability. In the development of this student worksheet, a 4D development model is used. The 4D model (Four D) was developed by S. Thiagarajan et al. [25]. The 4D model has four stages: the defining, the design, the development, and the dissemination. In this research, the stages are done only until the design stage. Figure 1 shows the 4-D model development procedure performed.
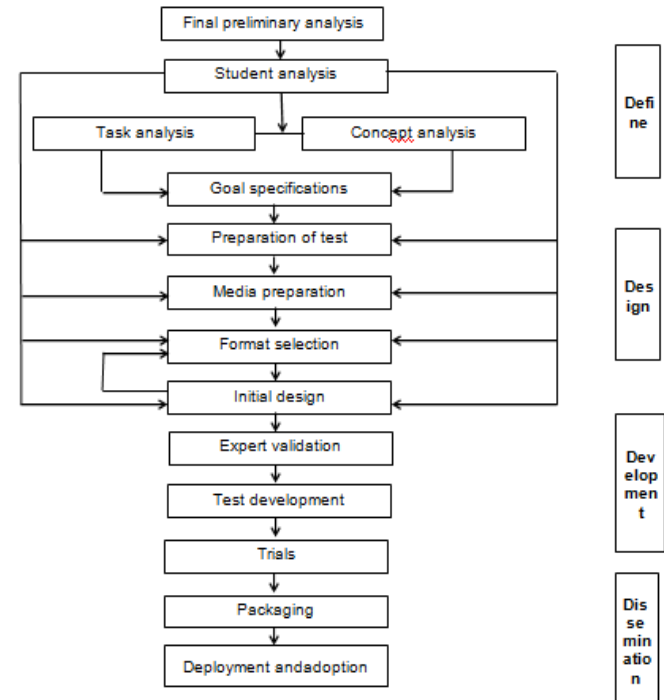

Fig. 1: 4-D Model Development Procedure (Source: adapted from Thiagarajan [25])

This research was conducted in class VIII MTs Mu'allimmat Yogyakarta. Subjects in this research were teachers, students, material experts and media experts. Data collection methods used in this research are interviews, questionnaires, and tests. Instruments used in the form of validation sheet, teacher response questionnaire, student response questionnaire, mathematical representation and interview guidance test. Interviews were conducted with teachers and students to find out the curricula and character of students in the school. The validation sheet is addressed to material experts and media experts. That questionnaire response of students and teachers is given after the testers try on the material. The test of student representation ability is given before and after the use of the student worksheet, so it is known whether there is an improvement in student representation ability.

Data analysis technique in this research is using qualitative data analysis according to Miles \&Huberman [26], i.e., data reduction, data presentation, and conclusion. Data obtained from observations and interviews conducted in schools are then summarized and summarized. From the analysis results obtained a clear picture of the things that are required in the design of student worksheets to be done.

\section{Results and Discussion}

In the 4D development model, several stages are done as follows:

\subsection{Define Stage}

At this stage, the needs analysis activities and requirements in the development of the student worksheet. At this stage there are five stages:

Stage 1: The final preliminary analysis is the activity of assessing the curriculum to know the competence or the material to be developed in the student worksheet. The result is that MTs Mu'allimat Yogyakarta uses the 2013 curriculum which refers to Permendikbud Number 68 the Year 2013 on basic competence and Structure of Junior High School curriculum. This data is obtained based on observations and interviews conducted on mathematics teachers at MTs Mu'allimat Yogyakarta.

Stage 2: Analysis of students undertaken to determine the character and academic ability of students who became a consideration in the preparation of student worksheets. In the student analysis stage, it is found that students of MTs class VIII are generally in the age range 13-14 years. The results of student analysis also show that students still have difficulty in representing real prob- 
lems into mathematical form. Observations and interviews performed showed a good response from students related to the development plan of this mathematical worksheet.

Stage 3: Analysis of the material that is activities identifying, detailing, and systematically compiling the materials to be written on the student worksheet. Material analysis can be that even grade VIII Semester material is still difficult to be understood by students. Some of the interviewed students expressed difficulties in understanding the real opportunities. Therefore, the material taken in this development is the material of opportunity.

Stage 4: Task analysis, which is the activity of identifying the primary skills required in the learning appropriate to the curriculum, and analyzing a skill that will be developed in the student worksheet. In this case, the development of this student worksheet aims to improve the ability of mathematical representation.

Stage 5: Formulate objectives, namely activities to formulate goals in learning (indicators of learning) by the analysis of the material. The purpose of making this student worksheet product is to facilitate the student in representing the real problem into the mathematical form. Also, with the use of learning cycle students are also expected to be more independent to develop mathematical skills.

\subsection{Design Stage}

At this stage is done in the design activities to develop student workbooks based on the learning cycle. Activities undertaken at this stage of the design is to create a draft student worksheet based on the learning cycle, arranging layout, design, etc., as well as designing the observation draft and assessment instruments. In making the student, the worksheet is divided into several sections shown in Figure 2 below.

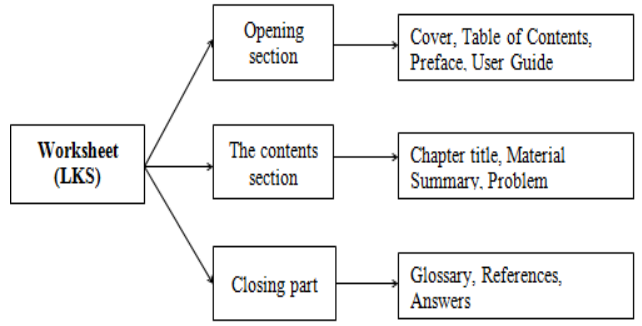

Fig. 2: The composition of the worksheet section

The opening section of the student worksheet contains the cover, table of contents, introduction, usage instructions. This section is based on results obtained from interviews and observations made to students. The opening section is arranged with great interest so that students feel attracted to the student worksheet and feel happy in the learning. The opening section of the student worksheet is shown in Figure 3 below.

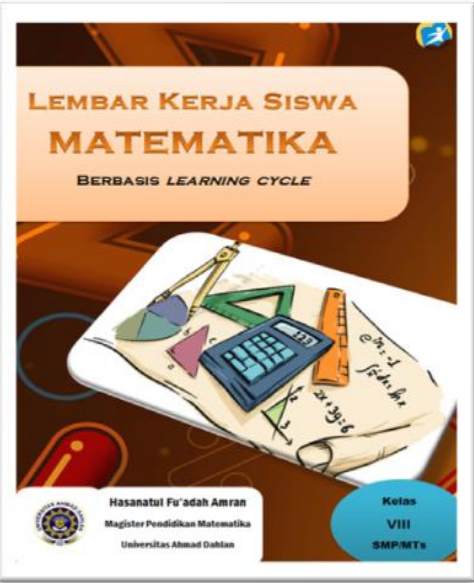

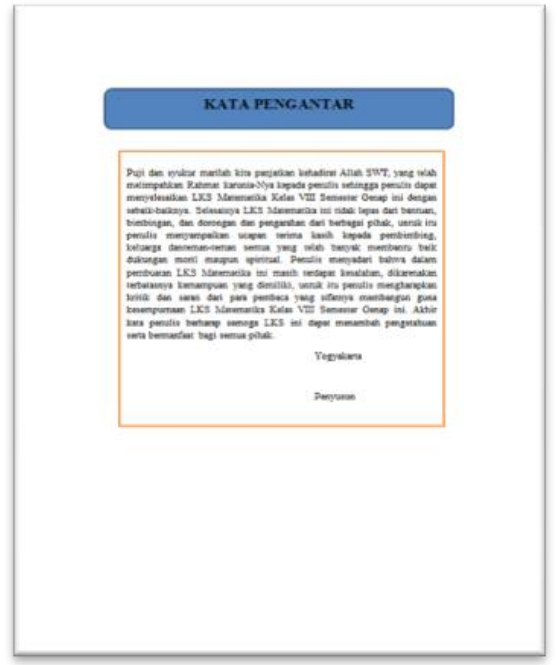

Fig. 3: The opening section of student worksheet (cover, table of contents)

The contents of the student worksheet contain chapter titles, material summaries, exercise questions, and evaluations. In this section are included stages in the learning cycle that is Engage (interest generator), Explore, Explain, Elaborate (deepening concept), and Evaluate. Stage engage (interest generator), on this stage students are given the opportunity to awaken and develop their interest and curiosity about the topic to be taught. The stage of exploring is the stage where students are given the opportunity to test their fundamental knowledge and ideas. Stages explain, at this stage students are introduced with new concepts, laws, or theories. Stages elaborate (deepening of the concept), aiming for students to apply the symbols, definitions, concepts, and skills on issues related to the material. The last stage is evaluated, teachers pay attention and observe the ability and skill of student related to comprehension of the taught material. The stages are expected to help students to be active in learning activities undertaken. Students are also expected to master the subject matter and train students' mathematical representation skills. This section of content contains a summary of materials, exercises, and evaluations tailored to the stages in the learning cycle. The indicators of mathematical representation prepared the exercises and evaluations. To find out whether or not there is an increase in the ability of mathematical representation in which students can hold pretest and post-test before and after the use of student worksheet. The contents of the student worksheet are shown in Figure 4 below.

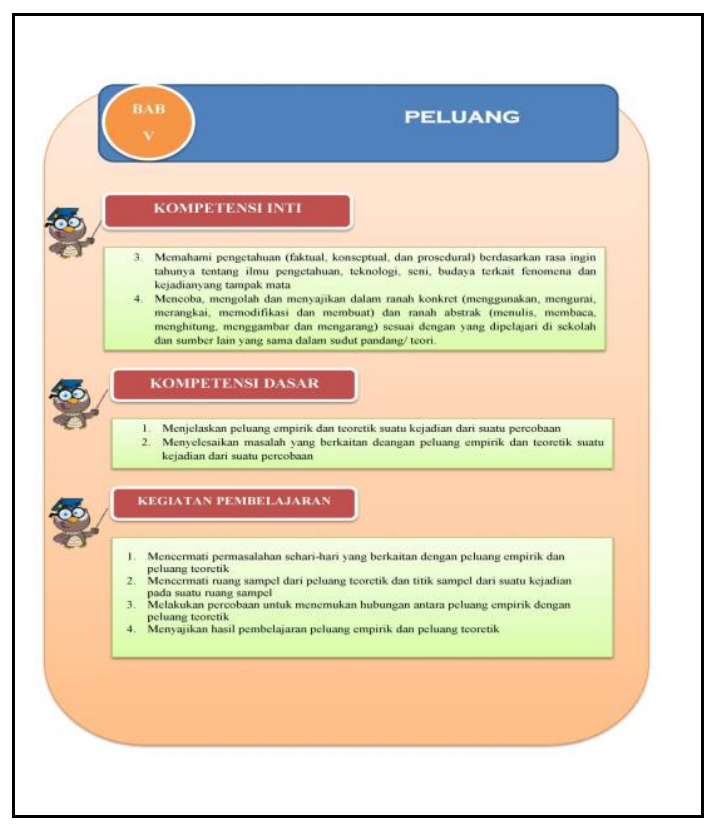



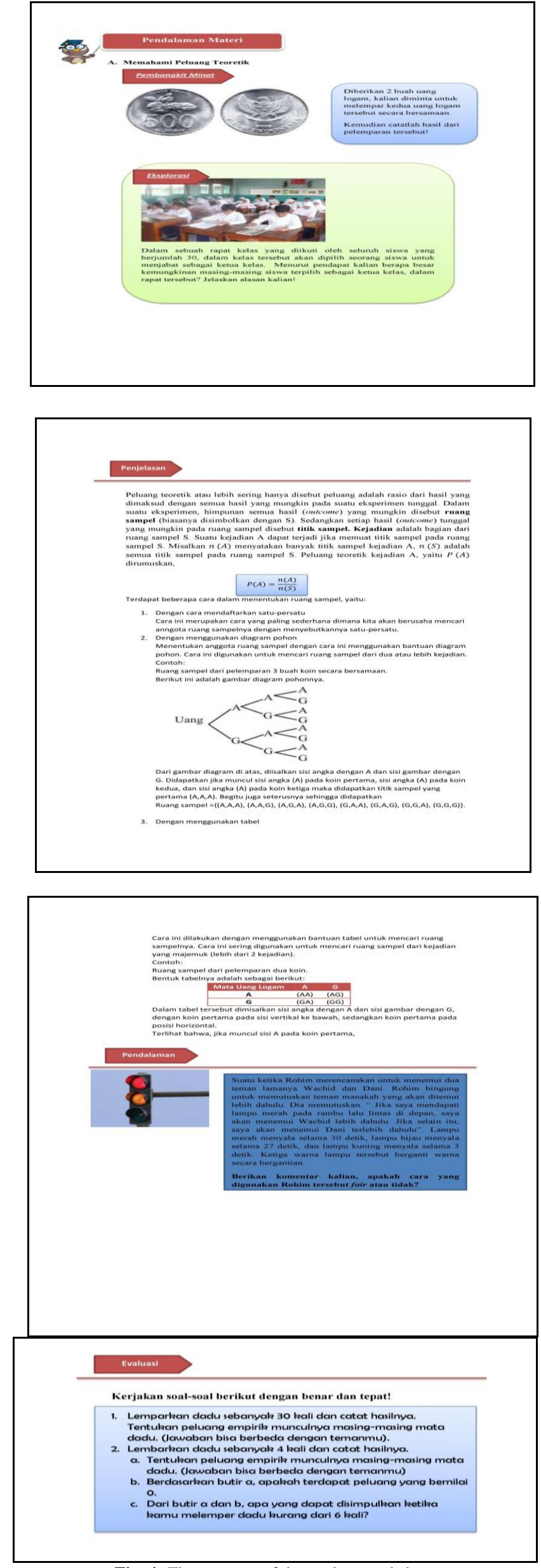

Fig. 4: The contents of the student worksheet
$\mathrm{T}$

The cover section of the student worksheet consists of a glossary, bibliography, and answer key. This research is limited only to the defining stage (define). However, to be more explicit about the stages in $4 \mathrm{D}$ will proceed to the next stage of development (development) and dissemination stage (dissemination).

\section{Conclusion}

This research resulted in student worksheet design based on a learning cycle that can help improve students' mathematical representation. Development is done by development method and 4D development procedure that is: Define Design, Development, and Dissemination. Components of the student worksheet, cover, introduction, table of contents, user manual, basic competence, core competencies, achievement indicators, material summary, action stages and evaluation. The student worksheet contains the learning cycle stages of Engage, Explore, Explain, Elaborate, and Evaluate. Indicators of analytical representation capabilities are also included in the learning cycle stages in this part of the student worksheet. For further development will proceed at the stage of development and dissemination.

\section{References}

[1] NCTM (2000), Principles and standards for school mathematics. USA: Association Drive, Reston.

[2] Hwang WY, Chen NS, Dung JJ \& Yang YL (2007), Multiple representation skills and creativity effects on mathematical problem solving using a Multimedia Whiteboard System. Educational Technology \& Society vol. 10, No. 2, pp. 191-212.

[3] Elia I (2004), Multiple representations in mathematical problem solving: exploring sex differences.

[4] Gagatsis A \& Elia I (2004), The effect of different modes of representation on mathematical problem solving. Proceedings of the 28th Conference of the International Group for the Psychology of Mathematics Education vol. 2, pp. 447-454.

[5] Zazkis R. \& Liljedahl P (2004), Understanding prime: the role of representation. Journal for Research in Mathematics Education vol. 35, no. 3, pp. 164-186.

[6] Kalathil RR. \& Sherin MG (2000), Role of students representation in the mathematics classroom. Fourth International Conference of the Learning Sciences pp. 27-28. Mahwah, NJ: Erlbaum.

[7] Michaelidou N, Gagatsis A \& Pantazi DP (2004), The number line as a representation decimal number: A research with sixth grade students. Journal for Research in Mathematics Education vol. 38, pp. 173-192.

[8] Harries T \& Barmby P (2006), Representing Multiplication. Proceeding of the British Society for Research into Learning Mathematics vol. 26, no. 3, pp. 25-30.

[9] Neria D \& Amit M (2004), Students preference of non-algebraic representations in mathematical communication. Proceedings of the 28th Conference of The International Group for The Psychology of Mathematical Education vol.3, pp. 409-416.

[10] Chen MJ, Lee CY \& Hsu WC (2015), Influence of mathematical representation and mathematics Self-efficacy on the learning effectiveness of fifth graders in Pattern Reasoning. International Journal of Learning, Teaching and Educational Research vol.13, no.1, pp. 1-16.

[11] Sahendra A, Budiarto MT \& Fua Y (2018), Students' representation in mathematical word problem-solving: Exploring students' Self-efficacy. Journal of Physic: Conference Series.

[12] Güler G \& Çiltaş A (2011), The visual representation usage levels of mathematics teachers and students in solving verbal problems. International Journal of Humanities and Social Science vol. 1, no. 11, pp. 145-154.

[13] PISA (2015), Result in Focus.

[14] Halat E \& Peker M (2011), The impacts of mathematical representations developed through Webquest and Spreadsheet activities on the motivation of pre-service elementary school teachers. TOJET: The Turkish Online Journal of Education Technology vol. 10, no. 2, pp. 259-263.

[15] Lorsbach AW (2002), The Learning Cycle as a Tool for Planning Science Instruction. 
[16] Trowbridge LW \& Bybee RW, Teaching Secondary School Science. Upper Saddle River, NJ: Merrill-Prentice Hall, (1996).

[17] Liu TC, Peng H, Wu WH \& Lin MS (2009), The effects of Mobile Natural-science learning based on the 5E Learning Cycle: A case study. Educational Technology \& Society. vol. 12, no. 4, pp. 344358.

[18] Bybee R W (2009). The BSCS 5E Instructional model and $21^{\text {st }}$ century skills. Biological Sciences Curriculum Study (BSCS).

[19] Abudulkadir \& Ahmed (2013), The effect of the 5E Learning Cycle model in teaching trigonometry on students academic achievement and the permanence of their knowledge. International Journal on New Trends in Education and Their Implications vol. 4, no. 1, pp. 73-87.

[20] Tezer M \& Cumhur M (2017). Mathematics through the 5E Instructional model and mathematical modelling: The Geometrical Objects. Eurasia Journal of Mathematics Science and Technology Education vol. 13, no. 8, pp. 4789-4804.

[21] Yeni N, Suryabayu EP \& Handayani T (2017), The effect of teaching model 'Learning Cycles 5E' toward students' achievement in learning mathematics at $\mathrm{X}$ years class SMA Negeri 1 Banuhampu 2013/2014 Academic Year. Journal of Physic: Conference Series.

[22] Toheri \& Winarso W (2017), Improving algebraic thinking skill, beliefs and attitude for mathematics through Learning Cycle based on beliefs. Munich Personal RePEc Archive.

[23] Merdekawati S \& Lestari HP (2017), Developing student worksheet in english based on Constructivism using problem solving approach for mathematics learning on the topic of Social Arithmetics. IOSR Journal of Mathematics (IOSR-JM) vol. 13, no. 1, pp. 30-38.

[24] Zulyadaini (2017), A development of students' worksheet based on Contextual Teaching and Learning. Advances in Social Science, Education, and Humanities Research (ASSER) vol. 149, pp. 127 129.

[25] Thiagarajan S, Semmel DS \& Semmel MI, Instructional Development for Training Teachers of Exceptional Children. Indiana: Indiana University Bloomington, (1974).

[26] Miles MB, Huberman AM \& Saldana J, Qualitative Data Analysis, A Methods Sourcebook, Edition 3. USA: Sage Publications. Translated by Tjetjep Rohendi Rohisi. Jakarta: Universitas Indonesia, (2014). 